\title{
Church Uniforms as an Indigenous Form of Anglicanism: A South African Case Study
}

\author{
Beverley Haddad ${ }^{1}$ \\ haddad@ukzn.ac.za
}

\begin{abstract}
African women members of the Mothers' Union in South Africa have forged a neo-indigenous expression of Christianity best expressed in the characteristics of the manyano movement (women's prayer groups) which include extempore prayer and preaching, extensive fundraising, and the wearing of a church uniform. These women had to resist the restrictions placed upon them by women missionaries and church leadership from England, which included the abolishment of the church uniform during the 1950s. The article traces their struggle of resistance during this period and shows how they fought to wear a uniform and so identified themselves with the movement of women's prayer unions existing in other churches. It also addresses the significance of the uniform as identified by elderly women from Vulindlela, KwaZuluNatal, South Africa and suggests some of the existing ambiguities of the church uniform in the current church context.
\end{abstract}

KEYWORDS: African women, Church of the Province of South Africa, church uniforms, colonialisms, manyano movements, Mothers' Union, South Africa

\section{Indigenous African Women's Expression of Christianity in South Africa}

Indigenous African women's expression of Christianity in South Africa is intricately intertwined with both the process of colonization and with the missionary enterprise of the late nineteenth century. A number of scholars have indicated the Church's role in the process of colonization

1. Professor Beverley Haddad is Senior Research Associate in the School of Religion, Philosophy and Classics, University of KwaZulu-Natal, Pietermaritzburg, South Africa. 
of African women and girls through the missionary enterprise. ${ }^{2}$ Cherryl Walker, in tracing gender patterns within the migrant labour system between 1850 and 1930, alludes to the role Christianity played in reinforcing sanctions against female mobility and independence. ${ }^{3}$ Others, such as Jacklyn Cock and Modupe Labode have argued that mission education for girls was based on the Victorian ideal of motherhood and domesticity. ${ }^{4}$ In the minds of women missionaries, 'the kraal' of the heathen African woman needed to be transformed into a home in which Christianity could flourish. One of the major concerns of female missionaries at this time was the necessity of inculcating the ideal of a male breadwinner, along with a dependent housekeeping wife and mother and dependent school-going children, among the African women and girls they worked with in the cities. However, argues Labode, this transformation was also necessary so that young girls could be trained for domestic service in the homes of colonial administrators and some missionaries. ${ }^{5}$

African women were encouraged by the missionaries to meet weekly to pray together. They then used these meetings to prepare the young converts for domestic service by teaching them skills such as sewing, washing and laundering as they saw appropriate to an ideal Victorian home. By the turn of the twentieth century, African Christian women were meeting regularly together in groups that had been nurtured by female missionaries. ${ }^{6}$ Deborah Gaitskell has referred to these meetings as training for 'devout domesticity'. ${ }^{7}$ Attempts at 'creating' women

2. I use the term 'African' in this article to refer to women who are indigenous to the African continent.

3. C. Walker, 'Gender and the Development of the Migrant Labour System c. 1850-1930: An Overview', in C. Walker (ed.), Women and Gender in Southern Africa to 1945 (Cape Town: David Philip, 1990), pp. 168-96.

4. See J. Cock, 'Domestic Service and Education for Domesticity: The Incorporation of Xhosa Women into Colonial Society', in Walker, Women and Gender, pp. 76-96, and M. Labode, 'From Heathen Kraal to Christian Home: Anglican Missionary Education and African Christian Girls, 1850-1900', in F. Bowie, D. Kirkwood and S. Ardener (eds.), Women and Missions: Past and Present, Anthropological and Historical Perceptions (Providence and Oxford: Berg Publishers, 1993), pp. 126-44.

5. Labode, 'From Heathen Kraal to Christian Home', p. 134.

6. D. Gaitskell, 'Female Mission Initiatives: Black and White Women in Three Witwatersrand Churches, 1903-1939', PhD thesis, University of London, 1981, pp. 144-72.

7. D. Gaitskell, 'Devout Domesticity?' A Century of African Women's Christianity in South Africa', in Walker, Women and Gender, pp. 251-72. 
through this ideology of 'devout domesticity' were, however, not always met without resistance in this early period of colonization. Labode refers to a number of incidents of dissent where young girls were clearly more interested in 'book learning' than in the 'domestic education' the women missionaries deemed necessary for them. ${ }^{8}$ Gaitskell, however, notes that Victorian Christianity 'offered a contradictory package to African women: a way of escape from some of the constraints of pre-Christian society and yet a firm incorporation into the domesticity and patriarchy of Christian family life'. ${ }^{9}$ So while mission education was often a servant of colonialism, it also worked towards offering independence for some individual young women.

The prayer groups of African women, nurtured by female missionaries with a focus on the home, were established at a time when increasing industrialization was threatening family life. By the early 1920s these groups were known as manyanos (prayer unions). ${ }^{10}$ The term, manyano was first coined by the Methodist women to refer specifically to their weekly meetings known as prayer unions. ${ }^{11}$ Increasingly, it was adopted by women from other denominations when referring to their church organizations.

During the 1930s poverty was rife among urban African families. Urban women increasingly became full-time domestic servants living in the 'white suburbs' away from their children. In the rural areas family life was also under siege. By this stage, influx control laws were in operation, which increased the male migrant labour workforce, and in effect left millions of rural women also struggling to survive on their own and unable to find easy access to the cities. They had to struggle against their family life being destroyed by the structural realities of the migrant labour system. Thus, for both urban and rural women, family life became something to fight for rather than against. It was the support network of manyano groups with their emphasis on family life that increasingly played a central role in the neo-indigenous expression of African women's Christianity.

\section{The Mothers' Union and the Manyano Movement}

The Mothers' Union (MU) of the Anglican Church, with its strong emphasis on mothering and family life, was introduced into South Africa

8. Labode, 'From Heathen Kraal to Christian Home', pp. 136-41.

9. Gaitskell, 'Devout Domesticity?', p. 254.

10. Gaitskell, 'Female Mission Initiatives', p. 146.

11. See M. Brandel-Syrier, Black Woman in Search of God (London: Lutterworth, 1962), pp. 15-16. 
within the contextual ideology of 'devout domesticity' as promulgated by female missionaries sent by the Church of England. As an organization it was nurtured through the early decades of the twentieth century, when African women were struggling for the survival of family life in both urban and rural areas.

While most of the manyano groups established in the mission initiated churches were particular indigenous expressions of African Christianity, the MU was the only organization that was a 'colonial import', having its roots outside of the African continent. All other women's church organizations in the mission initiated Churches were started by missionaries for African women only. The MU on the other hand, was an organization with large numbers of white women in South Africa. As will be argued below, there was much resistance by women missionaries and the church leadership to African branches of the MU taking on the characteristics of a manyano, particularly the wearing of the church uniform. However, it was through the strategies and struggles of African Anglican women that today the MU is an integral part of the indigenous manyano movement, while simultaneously ascribing to the mission statement of its mother organization in England. The Church of the Province in Southern Africa (CPSA), now known as the Anglican Church of Southern Africa (ACSA), spent the first half of the twentieth century attempting to 'regularize' MU branches in African communities away from their ever-increasing manyano identity with its emphasis on extempore prayer and preaching, the wearing of identifiable uniforms and fundraising activities. ${ }^{12}$

A number of scholars have referred to the ongoing pressure on African Anglican women to conform to the identity of the MU as defined by the headquarters of the organization in London. Gaitskell, in a study focusing on women's organizations within the Anglican, Methodist and American Mission Board Churches, argues that the Anglicans' history was different from the other two Churches in that much greater control over indigenous women was exercised by the missionaries. ${ }^{13}$ Likewise, Brandel-Syrier, conducting research in the 1950s on manyanos, while recognizing Anglican groups as part of this movement, points to a different history and ethos. ${ }^{14}$ Brian Pauw's work on manyano groups in the Northern Cape, South Africa, also confirms

12. For a fuller discussion of these practices, see B. Haddad, 'African Women's Theologies of Survival: Intersecting Faith, Feminisms and Development', PhD thesis, University of Natal, 2000, pp. 277-93.

13. See Gaitskell, 'Female Mission Initiatives'.

14. See Brandel-Syrier, Black Woman in Search of God. 
that Methodist women had greater freedom than Anglican women to conduct their affairs. ${ }^{15}$

Numerous strategies of control were introduced into the MU meetings of African women. Branches were established only with consent from the male priest who was very often a missionary from England. ${ }^{16}$ Even indigenous Anglican male priests insisted on attending the MU meetings of African women as a way to exercise strict control over their proceedings. ${ }^{17}$ Control was also exercised from the London office of the MU who stipulated clear guidelines on how MU workers sent to South Africa were to carry out training in the 'Bantu' branches. These guidelines were set out in the Mothers' Union Handbook for the Use of Bantu Branches which stated that each branch could only have an indigenous leader who was 'chosen from the church members and approved by the Priest-in-Charge and the Mothers' Union Worker'. ${ }^{18}$ Set duties were laid down for these branch leaders. Materials published by the London office suggest that the training of branch leaders was a key aspect of the work of the MU worker. ${ }^{19}$ It seems that branch leaders 'reported' to the MU worker who saw it as her duty to carry out teaching and training in the branch, to check financial records, to visit MU projects and so forth. The London office supported (and controlled) the work not only through human resources, but provided the necessary financial support through grants for salaries, transport and for other costs.

Control over the MU branches was not just exercised by the priests and MU workers; for decades the bishop's' wives were the titular heads of the organization in each diocese. They carried the responsibility of reporting on behalf of their diocese to the central office in England. Internally within South Africa, MU matters from the various dioceses would be discussed informally by the bishop's' wives when they met at

15. B.A. Pauw, Christianity and Xhosa Tradition: Belief and Ritual among Xhosa Speaking Christians (Oxford: Oxford University Press, 1975), p. 93.

16. 'Questions and Answers on the Three Objects of the Mothers' Union', March 1946-March 1947 (AB1018 Mother's Union, CPSA Archives, William Cullen Library, University of Witwatersrand), p. 4.

17. Brandel-Syrier, Black Woman in Search of God, p. 92.

18. 'Mothers' Union Handbook for the Use of Bantu Branches' (AB1018 Mothers' Union, CPSA Archives, William Cullen Library, University of Witwatersrand), p. 5.

19. 'Notes for Talks on the Three Objects of the Mothers' Union for the Use of Enrolling Members and Speakers', March 1946-March 1947 (AB1018 Mothers' Union, CPSA Archives, William Cullen Library, University of Witwatersrand), no page number. 
Episcopal Synod. This pattern of leadership continued until as late as 1954, when a Provincial Council of the MU was inaugurated and a constitution finalized a few years later. ${ }^{20}$

It was during this decade of the 1950s that the colonial hierarchy of the Anglican Church attempted to exercise even greater control over the activities of the African MU branches. Every attempt was made at this time to bring the African members of the MU in South Africa into line with their English counterparts.

In the Anglican groups, members must be admitted by a priest; unmarried mothers and divorced women are prohibited from membership. An exactly prescribed order of service must be followed and to this end, each member receives a special Form of Service from which the prayer formulae are read and the hymns sung. No extempore prayer or spontaneous choice of hymns is allowed ... The 'Praying and Preaching', which is the very raison d'être of the Manyanos, is obliterated. One address only is allowed to be given 'by the priest or the enrolling member, or some responsible person if requested.' A list of approved speakers for the Mothers' Union is available. This address may deal with purely spiritual subjects, but also with more general and everyday problems of Christian mothers. ${ }^{21}$

Strong campaigns were waged to rid the MU of common elements that it shared with manyano groups of other denominations, such as extempore praying and preaching, compulsory uniforms, fundraising and evangelism. ${ }^{22}$ While Thursday meetings continued, complete authority of these meetings rested with the priest, who was required to be present and the wearing of church uniforms was forbidden in Natal. ${ }^{23}$ Despite this promulgation, MU members resisted and the wearing of the church uniform remained a key requirement of membership of the MU.

\section{The Mothers' Union and the Wearing of the Church Uniform}

Thursday was and remains manyano-day, when women meet usually in the homes of one of the members. This tradition probably developed from the practice of launder-women fetching the washing on Monday from their employers, washing on a Tuesday, and ironing and

20. 'The Mothers' Union Constitution for the Province of South Africa', November 1957 (AB1018 Mothers' Union, CPSA Archives, William Cullen Library, University of Witwatersrand), p. 2.

21. Brandel-Syrier, Black Woman in Search of God, pp. 92-93.

22. Gaitskell, 'Female Mission Initiatives', p. 168.

23. Brandel-Syrier, Black Woman in Search of God, pp. 92-93. 
returning the washing on a Wednesday. ${ }^{24}$ Increasingly, as women moved into full-time domestic service, Thursday became recognized as the designated 'day off' for African women. ${ }^{25}$ It is primarily the distinctive church uniforms worn by manyano women that mark this day as 'women's day'. Each denomination wears a distinct uniform that usually includes a skirt, blouse, girdle and hat in a variety of colours enabling women to identify one another immediately.

Members of the MU wear a uniform, consisting of a black skirt, hat and girdle, and a white (and/or purple) blouse. ${ }^{26}$ Joining the MU is through a formal ritual ceremony of 'robing' where in many congregations the uniform is placed on the altar and officially blessed by the priest after the women have made their MU promises. In my experience, new members are ceremoniously led out of the church carrying their uniforms by the older members of the MU. The congregation waits patiently singing choruses while the women don their uniforms. This ritual has come to be known as the 'blousing' ceremony.

But African Anglican women, particularly in Natal, had to resist the attempts of missionaries and bishops to ban the uniform, as indicated earlier. In a memo sent from the Bishop of Natal on 30 March 1933, ten discussion points were offered for guidance (and further discussion) to MU workers who were all missionaries from England at this time. One of the points noted under the heading 'Uniform' was 'that the idea of wearing uniforms should be discouraged; it was thought that the [MU] badge would be sufficient' ${ }^{27}$ At a conference for African members of the MU of the Diocese of Natal in 1936, the Diocesan President, Mrs Fisher, 'informed members that [the] uniform would undermine the integrity of the organisation' ${ }^{28}$ Livingstone Ngewu suggests that the issue of the uniform was raised numerous times in conference with African members of the MU in the Diocese of Natal, 'but Mrs Fisher remained adamant that there was no definite uniform for the members authorized by the Mothers' Union' ${ }^{29}$

24. Gaitskell, 'Devout Domesticity?', p. 257.

25. Brandel-Syrier, Black Woman in Search of God, p. 27.

26. The significance of the colour of the uniform needs further investigation. One suggestion is that it was in the late 1930s in the Diocese of Johannesburg, that the MU authorities 'allowed' the uniform, provided that it was a black skirt and white blouse; see L.L. Ngewu, Listening to the Silent Voices of the MU: The Centenary History of the MU in the CPSA (Cape Town: CPSA, 2004), p. 178.

27. Memo from Bishop's House, Vryheid, Natal, 30 March 1933 (MU/05/005/ 07/50, Mothers' Union Central Archives, Lambeth Palace Library, London).

28. Ngewu, Listening to the Silent Voices of the MU, pp. 64-65.

29. Ngewu, Listening to the Silent Voices of the MU, p. 65. 
The debate around the wearing of the church uniform continued to rage with 'bishops' wives and MU Diocesan workers vehemently opposing its use. ${ }^{30}$ On 26 March 1958, Mrs S.C. Lorato, the 'Special Secretary for [the MU] Lady Day' from St Phillips Mission in Vryburg, Natal wrote directly to the 'President' of the MU at the London Headquarters on behalf of the branches in the area. ${ }^{31}$ She indicates that at the first Lady Day celebration in 1957 when all the African MU members came together, the issue of the wearing of the uniform arose. Mrs Wade, the MU worker in Natal, had suggested that they only wear the uniform on the first Sunday of the month. The different rural branches in the area were meant to discuss this suggestion and report back. This, she indicates, never happened, and so the matter was discussed once more at the second Lady Day celebration in 1958. Mrs Lorato then goes on to request that they be allowed to wear the uniform every Sunday, especially when there is a Eucharist service. '... We Africans are not all alike. Some are very poor. And the question of uniform helped to let us all look the same. In one way or the other, it is something that helps us in our Christian life. ${ }^{\prime 32}$

From the correspondence, it becomes clear that the letter was received by the Overseas Secretary of the MU in London, Mrs Dorothy Roberts. On 14 May 1958, she first writes to Mrs Wade, the MU worker, and informs her about the letter. She indicates that before she can respond to Mrs Lorato, she would value some background to the discussion as 'we have heard from many parts of Africa, both the value and the difficulties which the wearing of the uniform causes.... ${ }^{33}$ Mrs Wade responds extensively on 20 May 1958 indicating that the uniform is 'doing more harm than good' ${ }^{34}$ She goes on to say that her concern is that the uniform is worn all the time and that she has concluded 'that too many women join [the MU] just to don the uniform - what membership means is nothing to them - they carry on with all their old bad habits.... ${ }^{35}$ As a result, Mrs Roberts finally

30. See Gaitskell, 'Female Mission Initiatives', p. 168.

31. Letter from Mrs S.C. Lorato to 'President of the MU', London, 26 March 1958 (MU/05/005/07/50, Mothers' Union Central Archives, Lambeth Palace Library). The correspondence includes handwritten letters, and 'Lorato' is used here for a person whose name could also be construed as 'Lacto' or otherwise in different documents.

32. Letter from Mrs S.C. Lorato to 'President of the MU', London.

33. Letter from Mrs Roberts to Mrs Wade, 14 May 1958 (MU/05/005/07/50, Mothers' Union Central Archives, Lambeth Palace Library).

34. Letter from Mrs Wade to Mrs Roberts, 20 May 1958 (MU/05/005/07/50, Mothers' Union Central Archives, Lambeth Palace Library).

35. Letter from Mrs Wade to Mrs Roberts, 20 May 1958. 
responds to Mrs Lacto on 16 June 1958 indicating that in England despite MU members coming from different economic backgrounds, they do not wear a uniform and only the MU badge. ${ }^{36}$ She continues:

I do know and understand your desire to show that you are witnesses to the teaching of Christ; but feel that if a uniform is worn it should be used only for church-going and for Mothers' Union meetings, and only by those who understand the meaning of the Objects [of the MU] for which we all stand, and are prepared to uphold them all day every day. To wear a Mothers' Union uniform, and to lead a life of bad example and poor witness, would bring shame and ridicule to the Mothers' Union and would not be allowed. I know that the whole matter is to be discussed at your Provincial Council in the autumn, and I hope that you will loyally abide by the decisions which are made there.... ${ }^{37}$

The discussions on the wearing of the uniform that took place at the MU Provincial Council were not clearly recorded. But from the correspondence by the new MU worker in the Diocese of Natal, Mrs Jane Hopkins, it is clear that she continued the campaign to abolish the uniform despite the clear indication by African Anglican women that it was important to them. In a letter to Mrs Marjorie Davey, the new Overseas Secretary at the MU Headquarters in London, she wrote on 23 July 1959:

We are trying to get a change of leadership [in the African branches of the $\mathrm{MU}]$ each year, and also to get the young wives to join. These do not want the old days of extemporary prayer and emotional hymn singing and uniform. I read somewhere that someone overseas admired the tidy appearance of some of our members in uniform. If only it was realized what a difficulty this uniform is! It has all the wrong associations. It is not recognized provincially and I am glad that in Natal it is now accepted almost everywhere that MU members do not wear it. You may not agree with this. The Africans love the uniform and women's societies in the hundreds of religious denominations which also exist, all have the uniform. By permitting it in the MU one lowers the standard immediately to the level of any women's guild, and it is this which we want to fight. ${ }^{38}$

From the response to the letter, it was clear that Mrs Davey did agree with the sentiments expressed by Mrs Hopkins:

Don't worry, we thoroughly agree with you on your feelings about uniform; when delegates from the South African dioceses were over here

36. Letter from Mrs Wade to Mrs Lorato, 16 June 1958 (MU/05/005/07/50, Mothers' Union Central Archives, Lambeth Palace Library).

37. Letter from Mrs Wade to Mrs Lorato, 16 June 1958.

38. Letter from Mrs Jane Hopkins to Mrs Marjorie Davey, 23 July 1959 (MU/ 05/005/07/50, Mothers' Union Central Archives, Lambeth Palace Library). 
for the World Wide Conference last year, the matter of uniform was discussed and it was again discussed at one of our recent committee meetings when Mrs Shell [Diocesan President] of Pretoria was present. We know what a menace uniforms were but feel that we cannot here at Mary Sumner House [MU Headquarters, London] issue a directive banning them; we feel it is something that must be handled by the South African Provincial Mothers Union. ${ }^{39}$

However the matter was handled by the South African Provincial Mothers' Union, their attempts to rid the MU of the wearing of a church uniform failed. African Anglican women chose to align themselves first and foremost with the indigenous manyano movement and donned the uniform they had chosen to declare their allegiance.

Elderly MU members from Vulindlela outside Pietermaritzburg, South Africa remembered the struggle during those days as they recounted their memories in interviews. 'They did not allow us to wear it [the uniform] and at that time many women joined other churches until the uniform issue was settled after being talked through by the Diocese' ${ }^{40}$ Another indicated the support they received from some of the indigenous male church leaders:

\begin{abstract}
Kwasekuba khona uMkhathekisi uGule wathi kufuneka sibe neyunifomu wathi asibe neziketi ezimnyama nanablawzi aphephli. AbaBhishophi abamhlophe bathi, abafundisi babelungu bathi uGule uzzonqunywa enkonzweni ngoba uthatha ingubo yabaBhishophi uphephli athi awugqokwe ngomama yayekwa ke iyunifomu ayangaba khona abanye basebewathengile amablowse aphephli ayekwa. Bangavuma yayekwa ke iyunifoma leyo kwahlalwa ke kwahamba kwahamba nje sengimdala nje kwaba yikhona iqhamuka futhi leyunifoma ukuthi asigqoke ublack and whithe ehe...

[There was [Mr] Gule, the catechist, who said that we should have a uniform. He said it should consist of white skirts and purple blouses. But the white bishops said that Gule will be removed from the leadership of the church because he is saying that mothers should wear the 'bishop's dress'. And so the uniform was abolished. Some women had bought purple blouses, but they had to stop wearing them. It remained like that until I was old, when the uniform was allowed and it was decided that we should wear black skirts and white blouses]. ${ }^{41}$
\end{abstract}

Another recounted how women would wear their uniforms to attend Eucharist services if led by a 'sympathetic' priest. If they knew the priest

39. Letter from Mrs Marjorie Davey to Mrs Jane Hopkins, 30 July 1959 (MU/05/005/07/50, Mothers' Union Central Archives, Lambeth Palace Library, London).

40. Interview with Mrs Violet Mhlongo, Vulindlela, 24 April 1998.

41. Interview with Mrs Miriam Zondi, Vulindlela, 24 April 1998. 
was not sympathetic, they would make a point of not wearing their uniform that particular Sunday. ${ }^{42}$ This was their strategy of resistance.

\section{The Significance of the Church Uniform}

In attempting to understand the significance of the church uniform historically, Gaitskell argues that adopting Western clothing was a sign by the first converts of a commitment to new religious beliefs. ${ }^{43}$ However, Western clothing lacked 'symbolic particularity' with little distinction between young and old, married or unmarried, widow or mother. ${ }^{44}$ The church uniform worn by manyano women could thus be interpreted as a reassertion of a distinctive Christian dress that proclaimed spiritual allegiance, advertised marital respectability, and was recognized as a reward for upright living. ${ }^{45}$ For manyano women the church uniform replaced Western clothing as the mark of Christian commitment. It also replaced the MU badge as a distinctive marking which was considered adequate corporate identification by white leaders, but was not sufficient for manyano members. ${ }^{46}$

Brandel-Syrier too argues from her research in the 1950s, that the church uniform is more than a symbol of corporate identification that indicates Christian commitment and status. ${ }^{47}$ There is a sacramental element to the wearing of the uniform. 'In the donning of the uniform there is transferred an essential quality which is not just associated with it as symbol, but is inherent in the uniform itself and thus conferred upon the wearer. ${ }^{48}$ Jean Comaroff confirms this view, suggesting that the uniform instantiates the ritual practice it represents and, as such, has a 'magical' quality. ${ }^{49}$ The uniform is not only a symbol, but has a substantial quality, inherent in itself, which is conferred on the wearer. In this sense, the uniform embodies supernatural powers that infuse the material world and become a resource for dealing with this reality. When women are admitted as members, their uniform is placed on the altar in church and prayers are said and in this way 'such items of clothing are believed to have been

42. Interview with Mrs Lilian Ngcobo, Vulindlela, 24 June 1998.

43. Gaitskell, 'Female Mission Initiatives', p. 215.

44. Gaitskell, 'Female Mission Initiatives', p. 215.

45. Gaitskell, 'Female Mission Initiatives', p. 215.

46. Gaitskell, 'Female Mission Initiatives', p. 216.

47. Brandel-Syrier, Black Woman in Search of God, p. 49.

48. Brandel-Syrier, Black Woman in Search of God, p. 49.

49. J. Comaroff, Body of Power Spirit of Resistance: The Culture and History of a South African People (Chicago: University of Chicago Press, 1985), p. 220. 
consecrated' ${ }^{50}$ Thus, it is seen as the only appropriate dress in which to receive Holy Communion, hence the plea by Mrs Lorato in 1958 to be allowed to wear the uniform every Sunday. In my experience during the 1990s, MU members choose to go to the grave with their uniform displayed on their coffin. ${ }^{51}$

Ha uyazi ukuthini ngiye ngifise ukuthi ngangcono ukube kuthiwa ngothi sengithule ngihambe nayo inyufoma yami bangifake konke nebhantshi nesigqokayo ngiqhamuke nje

[You know what I sometimes wish ... that when I die I can take my uniform with me; that they will dress me in my blouse and my hat so that I will appear as a complete person]. ${ }^{52}$

In interviews with elderly members of the MU at St Raphael's Church, Vulindlela, KwaZulu-Natal during the 1990s, it became clear that they believe that the uniform is more than a symbol that gives them a corporate identity. ${ }^{53}$ These are no ordinary garments. For the women they contain supernatural powers. When asked why putting on the uniform is important a common response is, 'Kimina nje ngiye ngizwe inginika amandla' [I always feel that it gives me power], ${ }^{54}$ and another, 'kufika amandla ehe ya' [the power comes, yes ...]. ${ }^{55}$ Some women would go as far as to say that when they put it on they are healed from physical illness: '...uma sengiyigqokayile noma ngigula ngiyasinda kuba khona ukusinda kimina' [...If I am wearing the uniform when I am sick, I get well; I become healed $]{ }^{56}$ '...ngcono nje konke ngoba noma ngigula ke nje uma ngike ngathatha yunufomu yami nje ngathatha imedani yami ngayigaxa lapha ngakhuleka ngiye ngizwe ngiba namandla' [...even if I am sick, once I take my uniform and put it on and pray, I feel the power] ${ }^{57}$ Other women alluded to a relief from 'not feeling well': 'Ngizwa ngiphila impela uma sengiyifakile ngizwa kuba mnandi impela egazini lami ngizwa ukujabula nje impela sengiyigqokayile sengihamba sengiphelele' [I feel better when I put it on, I feel good in my blood I feel happy when I have put it on and

50. Ngewu, Listening to the Silent Voices of the MU, p. 242.

51. See also Brandel-Syrier, Black Woman in Search of God, p. 49.

52. Interview with Mrs Josephinah Nene, Vulindlela, 24 April 1998.

53. Vulindlela, KwaZulu-Natal, South Africa is a semi-rural area outside the city of Pietermaritzburg. During the 1990s when the interviews were conducted it was an area under the jurisdiction of traditional leaders but has since been incorporated into the city of Pietermaritzburg and has become more urbanized.

54. Interview with Mrs Sophia Ntombela, Vulindlela, 6 May 1998.

55. Interview with Mrs Violet Mhlongo, Vulindlela, 24 April 1998.

56. Interview with Mrs Selinah Ndlovu, Vulindlela, 17 April 1998.

57. Interview with Mrs Sophia Ntombela, Vulindlela, 6 May 1998. 
I depart the house being complete]. ${ }^{58}$ The 'feeling better' suggests much more than a physical relief. It encompasses an overall sense of physical, mental and spiritual well-being, perhaps best summed up in the response that when the uniform is put on, 'Ingenza ngiphila iyangiphilisa' [It makes me feel alive]. ${ }^{59}$

This aliveness is both a spiritual aliveness and an aliveness that equips Vulindlela women to deal with the harsh physical realities of their world. ${ }^{60}$ The uniform provides 'status' as it gives a sense of dignity to the wearer, 'Ngiyayithanda ukuba ngiyigqoke iuniform ngoba sengathi kukhona ekukhiphe ngaphakathi enhlizweni yami yangibeka kwelinye ibanga' [I like to wear the uniform because it seems as if it has taken something bad out from inside my heart and has put me in a certain position] ${ }^{61}$ Putting on the uniform also strengthens, '...iyasiginisa iyunifomu...' [...the uniform strengthens us...]. ${ }^{62}$ 'Bese ngikhuthala ngisebenze ngikhuthale manje ngoba sengidle into enginika umdlandla wamandla' [Then I become hard working because I have eaten something which gives me strength]. ${ }^{63}$ 'Iyunifomu impela siyayithanda thina ngoba uma sihamba nje siya eSontweni kanje kodwa singagqokile uyabona singayifakile iyunifomu kuye kube sengathi asiphelele angathi izikhali zethu aziphelele' [We really like the uniform because if we go to church without wearing a uniform we feel as if we are not complete; as if our weapons are not complete]. ${ }^{64}$

James Scott, in describing the discursive acts of the oppressed, argues that what is proclaimed publicly in word and deed is only half the story. ${ }^{65}$ Public proclamations will always contain the hegemonic language of the dominant. Rather, it is in the realm of the hidden and in the disguised language of 'infrapolitics', the speech acts and a range of other practices carried out behind the backs of the dominant group that the voice of the oppressed is to be found. He further asserts that issues

58. Interview with Mrs Josephinah Nene, Vulindlela, 24 April 1998.

59. Interview with Mrs Selinah Ndlovu, Vulindlela, 17 April 1998.

60. The work of A.C. Henriques suggests that indigenous African Catholic women in KwaZulu-Natal have similar understandings of the value of their church uniform to those expressed by the Anglican women of Vulindlela. See A.C. Henriques, 'The Catholic Church in the Culture of Apartheid: The Case of Catholic Laity in Natal (1948-1965)', MTh thesis, University of Natal, 1996.

61. Interview with Mrs Violet Mhlongo, Vulindlela, 24 April 1998.

62. Interview with Mrs Sophia Ntombela, Vulindlela, 6 May 1998.

63. Interview with Mrs Violet Mhlongo, Vulindlela, 24 April 1998.

64. Interview with Mrs Sophia Ntombela, Vulindlela, 6 May 1998.

65. J. Scott, Domination and the Arts of Resistance: Hidden Transcripts (New Haven: Yale University Press, 1990). 
of dignity and autonomy should be privileged as 'weapons' of the dominated. ${ }^{66}$ Mrs Ntombela, in asserting her 'completeness' through the wearing of her church uniform which is her 'weapon', is asserting her autonomy and dignity in the face of oppression and a daily struggle for survival. The women of Vulindlela wear the uniform because it affords them dignity where they have none. Infused with God's power, it brings hope and comfort and healing in the face of illness. As they are provided with strength, they are able to carry out the physical demands made upon them in the everyday practices of their lives. The uniform is literally and figuratively a symbol of their autonomy and dignity.

\section{The Ambiguity of the Church Uniform}

The church uniform offered autonomy and dignity to African women, particularly to those living under the colonialism of the early 1900s and the apartheid system introduced in 1948 when the South African Nationalist government came to power. The racial discrimination endured by African women through these decades was compounded by the cultural oppression they faced as a result of a deeply entrenched African patriarchal society. So women wore their uniform because it created space for them to operate in the church in ways that were not normally open to them. In proclaiming their allegiance to the manyano movement through the wearing of the uniform, they aligned themselves with and in a space that they themselves had defined, away from domination. As indicated earlier, women such as Mrs Ngcobo showed that they were not passive but were actively resisting the restrictions placed on them by the Church authorities. In a delightful public irruption of what was once hidden, she confessed to me a hidden strategy against the restriction of the wearing of church uniforms: women only wore the church uniform to services where sympathetic clergy were officiating. They had a keen grasp of which priests were on their side and harnessed clergy support in tactically continuing their protest. Strategically navigating the church politics of the day, they resisted until they had ultimately secured the space they now enjoy to freely wear their church uniforms. ${ }^{67}$

Now that there is freedom to wear the church uniform, it must be acknowledged that in the current South African context there is some

66. Scott, Domination and the Arts of Resistance, p. xi.

67. It must be noted that women have been allowed to be ordained as priests since 1992. Further research needs to be conducted as to how this decision has influenced the practices of the MU. 
ambiguity as to its significance. Ngewu, in conducting interviews for his landmark publication, Listening to the Silent Voices of the MU: The Centenary History of the MU in the CPSA published in 2004, notes that the issue of the wearing of the church uniform is contested. He argues that the MU is divided into two groups; those who believe there would be no MU without a uniform and those who feel it should not be made obligatory for members. ${ }^{68}$ However, he found that in most Dioceses new members of the MU are expected to present their uniforms to the altar on the day of their admission to the organisation' ${ }^{69}$ Inherent in this discussion is the question of the extent to which the uniform is seen by women themselves as a tool of oppression, because the practice is that single mothers or those women who are divorced are precluded from wearing the uniform. ${ }^{70}$

My recent experience from an urban setting suggests that as more members of the MU become middle class, other forms of 'uniform' are adopted for regular worship. A growing practice seems to be the designing of more modern clothing from material that has been printed with the MU logo, which is then worn to an ordinary worship service. However, it seems that these same women continue to wear the church uniform on days of special significance in the Church year. ${ }^{71}$

\section{Conclusion}

Cordelia Moyse has written a definitive account of the history of the Mothers' Union in a number of countries including South Africa. ${ }^{72}$ She argues that in no other part of the world did the MU 'experience such a seismic shift in identity as in South Africa' where the entirely white membership of the early years had become dominated by African women in South Africa by the 1940s. ${ }^{73}$ These women were never passive recipients of the MU ethos and structure as handed down by the colonial authorities. They refused to accept Western thinking and practice, 'contesting on occasion MU teaching on its three objects

68. Ngewu, Listening to the Silent Voices of the MU, p. 175.

69. Ngewu, Listening to the Silent Voices of the MU, p. 242.

70. See L. Holness, 'Women's Piety and Empowerment: An Observer's Understanding of the Methodist Women's Manyano Movement', Journal of Theology for Southern Africa 98 (1997), pp. 21-31.

71. This practice of wearing alternative 'uniforms' requires further research as to its significance and origin.

72. C. Moyse, A History of the Mothers' Union: Women, Anglicanism and Globalisation, 1876-2008 (Woodbridge: Bodell Press, 2009).

73. Moyse, A History of the Mothers' Union, p. 150. 
concerning marriage, the family and the nature of prayer and worship ${ }^{\prime}{ }^{74}$ This refusal was no more clearly expressed as in their desire to wear a church uniform and to succeed in doing so.

The MU, as a part of the indigenous Christian women's movement in South Africa, is a sacred, sequestered, safe site which has been forged by African women themselves. It continues to maintain the elements of extempore prayer and preaching, fundraising, and the wearing of the church uniform (albeit with some ambiguity) and enables women to continue to express their spirituality in ways that are authentically African and Anglican.

74. Moyse, A History of the Mothers' Union, p. 151. 